\section{The Frugal Innovation Case of Solar-powered Automated Teller Machines (ATMs) of Vortex Engineering in India}

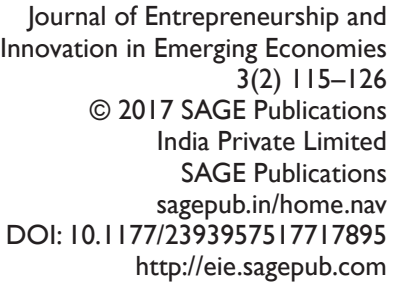

(SAGE

\author{
Nivedita Agarwal' \\ Alexander Brem ${ }^{2,3}$
}

\begin{abstract}
Constraint-based innovations are innovations that are conceived under conditions of scarcity for resource-constrained markets, often referred to as Bottom of pyramid (BoP) marketplace. One such type of constraint-based innovation, frugal innovation (also the focus of this study) has played an important role in providing affordable and accessible products and services to the customers at BoP. This study examines one of the successful frugal innovations from the Indian financial sector called Vortex solar based transaction systems (commonly known as rural ATMs) and offers a comprehensive analysis on the incorporated bottom-up product development process and innovation drivers. Study highlights the nine specific innovative design features of these machines that were mainly designed based on core customer requirements and unique challenges. Analysis reveals the importance of cost effective, easy to operate and sustainable solutions for customers at BoP and also showcase how frugal innovations are also facilitating solutions to address larger societal problems.
\end{abstract}

\title{
Keywords
}

Frugal innovation, automated teller machines, emerging markets, constraint-based innovation, India

\section{Scope and Purpose of the Case Study}

Constraint-based innovations are becoming a key driver for innovation worldwide. Especially in emerging markets like India, specific types of constraint-based innovations conceived under conditions of scarcity are gaining success. Frugal innovation is a type of constraint-based innovation that has

\footnotetext{
${ }^{1}$ Postdoctoral Researcher, Chair of Information Systems- Innovation \& Value Creation, Friedrich-Alexander-Universität Erlangen-Nürnberg (FAU), Germany.

${ }^{2}$ Full Professor, Chair of Technology Management, Friedrich-Alexander-Universität Erlangen-Nürnberg (FAU), Germany.

${ }^{3}$ Mads Clausen Institute, University of Southern Denmark (SDU), Denmark.
}

\section{Corresponding author:}

Nivedita Agarwal, Postdoctoral Researcher, Chair of Information Systems- Innovation \& Value Creation, Friedrich-AlexanderUniversität Erlangen-Nürnberg (FAU), Germany.

E-mail: nivedita.agarwal@fau.de 
contributed a lot to the successful evolution of Indian subsistence marketplace. This case introduces one such example of frugal innovation-Vortex solar-based transaction systems or so-called rural automated teller machines (ATMs) that enabled penetration of banking services in rural India. Specifically developed for unique conditions and requirements of rural India, the success of these solar-powered ATMs presents an appropriate case to gain further insights on frugal innovations and understand its impact on society at large.

\section{Theoretical Background}

Innovation as defined by the Organisation for Economic Co-operation and Development (OECD) is 'the implementation of a new or significantly improved product (good or service) or process, a new marketing method, or a new organisational method in business practices, workplace organisation or external relations' (Oslo Manual OECD/European Communities, 2005). It is described as the best-known indicator of organizational competitive advantage (Christensen, 1997; Drazin \& Schoonhoven, 1996). Eighty of the Fortune 500 companies that have focused on organic growth through innovations have 'earned handsome rewards' for the shareholders, compared to companies with lower rates of organic growth (von Krogh \& Raisch, 2009). However, being innovative is by no means a no-brainer that appears automatically. Companies in each industry struggle to be and stay innovative, so that a long-term competitive advantage is ensured. This is not only true for advanced economies but also for emerging ones. To gain competitive advantage in emerging economies, companies need to understand the unique conditions of these markets which are significantly different from advanced economies and develop innovative solutions that suffice local requirements (Agarwal \& Brem, 2012).

The global population, conceived in the form a pyramid, can essentially be split into three groups based on purchasing power parity. Located at the top of the pyramid there are 200-300 million people with more than $\$ 20,000$ income per annum, whereas in the middle there are 600-800 million people earning between $\$ 2,000$ and $\$ 20,000$. At the bottom of this pyramid (BOP) is the major part of the population with 5,500 million people that live with an annual income of less than $\$ 2,000$ (Prahalad, 2006). This BOP segment majorly residing in emerging markets has been largely ignored by the large Western multinationals. However, Prahalad (2002) was one of the first few researchers who argued for the existing profit potential at the BOP and emphasized the need for affordable innovative solutions for this specific customer segment. The eventual success of these affordable or constraintbased innovations garnered a lot of attention in both business and academia and resulted in various subtypes of innovations differentiated by the underlying motivation (Agarwal, Grottke, Mishra, \& Brem, 2017). Table 1 offers an overview of these different sub-types of constraint-based innovations that have been discussed so far in the literature. However, this case focuses only on one specific type of constraintbased innovation-frugal innovation.

Frugal innovations also defined as 'good-enough' and affordable solutions that suffice the needs of resource-constrained consumers (Zeschky, Widenmayer, \& Gassmann, 2011) are often confused with Jugaad. However, frugal innovations follow certain processes, product management methodologies and structures in the innovation approaches, which Jugaad lacks (Lacy, 2011; Prahalad \& Mashelkar, 2010). Therefore, such innovations do not constitute either a de-featuring the existing expensive products or arbitrage of labour or material costs. Rather it is a clean-slate approach of building an affordable solution from scratch and contradicts the top-down, sophisticated, R\&D-led development process followed in the Western world. Frugal innovations are cost-effective, simple, basic, compact, easy-to-use solutions that 
Table I. Different Sub-types of Constraint-based Innovations in Emerging Market Contexts

\begin{tabular}{|c|c|}
\hline Innovation Sub-types & Definition \\
\hline Jugaad & $\begin{array}{l}\ldots \text { is an improvisational approach to solving one's own or others' problems in } \\
\text { a creative way, at a low cost, in a short amount of time and without serious } \\
\text { taxonomy or discipline applied by people at the BOP as a result of poverty and } \\
\text { exigency. }\end{array}$ \\
\hline Frugal Innovation & $\begin{array}{l}\ldots \text { is a derived management approach, based on Jugaad, that focuses on the } \\
\text { development, production and product management of resource-saving products } \\
\text { and services for people at the BOP by achieving a sufficient level of taxonomy and } \\
\text { avoiding needless costs. }\end{array}$ \\
\hline $\begin{array}{l}\text { Frugal Engineering/ } \\
\text { Constraint-based } \\
\text { Innovation }\end{array}$ & $\begin{array}{l}\text {... describes a process-oriented approach to adapt existing technologies to } \\
\text { local challenges by dint of the integration of the local society in order to reduce } \\
\text { inherent development costs and time. }\end{array}$ \\
\hline Gandhian Innovation & $\begin{array}{l}\ldots \text { is an approach that takes advantage from the adaption of existing technologies } \\
\text { by integrating them into local context or/and establishing local expertise by } \\
\text { spillovers through collaborations in order to increase social wealth of people from } \\
\text { the BOP. }\end{array}$ \\
\hline Catalytic Innovation & $\begin{array}{l}\ldots \text { is an approach that focuses on social change by breaking down existing social } \\
\text { and economic structures and creating new market structures which involves new } \\
\text { development approaches of systematic, sustainable and system-shifting kind. }\end{array}$ \\
\hline Grassroots Innovation & $\begin{array}{l}\text {... represents a bottom-up development approach that includes social integrity } \\
\text { and local civilians as inventors by connecting people through social or technical } \\
\text { networks in order to develop ecologically and socially acceptable products and } \\
\text { services. }\end{array}$ \\
\hline Indigenous Innovation & $\begin{array}{l}\text {... considers technology transfers, predominantly technology inflows, from } \\
\text { developed to emerging countries and their effects on local entrepreneurs at the } \\
\text { BOP. }\end{array}$ \\
\hline Reverse Innovation & $\begin{array}{l}\text {... represents the development of new products in and for emerging countries by } \\
\text { developed or emerging market firms which will be introduced equally in developed } \\
\text { markets if the demand in developed markets is identified. The extreme case of } \\
\text { reverse innovation is the development of new products in emerging countries } \\
\text { which are only introduced in developed markets. }\end{array}$ \\
\hline
\end{tabular}

Source: Brem and Wolfram (2014, p. 19).

may use cutting-edge technology if necessary to lower the price. Table 2 describes the identifying characteristics of these innovations (Agarwal \& Brem, 2014).

\section{The Case: Vortex Solar-powered ATMs}

\section{Historical Background'}

Vortex Engineering was founded in 2001 as an incubation project at the Indian Institute of Technology (IIT), Madras, by L. Kannan, a mechanical engineer (Leena, 2011). As a founder of Vortex and also of a matriculation school in southern India (Tamil Nadu), he holds many design patents on Vortex ATM. 
Table 2. Characteristics of Frugal Innovation

\begin{tabular}{ll}
\hline Characteristics & Description \\
\hline Cost-effective & $\begin{array}{l}\text { Value for money, providing quality (not luxury) at prices that are affordable to BOP } \\
\text { customers } \\
\text { Do more with less, using minimal/least possible resources in the product } \\
\text { development efforts } \\
\text { Human-centric, intuitive designs that require little to no prior knowledge or training } \\
\text { to utilize }\end{array}$ \\
Easy-to-use & $\begin{array}{l}\text { Environment-friendly, considering both societal and environmental effects } \\
\text { Bustainable }\end{array}$ \\
Problem-centric & $\begin{array}{l}\text { Solution, customer-centric rather than technology- or product-centric } \\
\text { job done }\end{array}$ \\
No-frills & $\begin{array}{l}\text { Timely to market, faster to deploy and also considering all the aspects of business } \\
\text { from manufacturing to logistics }\end{array}$ \\
Fast-to-market & $\begin{array}{l}\text { Creating a novel creative solution which eventually disrupts the existing market and } \\
\text { helps to shape an entirely new market }\end{array}$ \\
Breakthrough &
\end{tabular}

Source: Agarwal and Brem (20I4, p. I2).

Apart from working as one of the managing directors of the company, he actively engages with local NGOs and other social groups working towards rural development.

In the period of 2004-2008, in collaboration with IIT Madras, Vortex designed its first rural ATM with totally new features. Vortex developed an innovative, low-powered ATM that consumed as low as 60 watts of energy and was able to function in adverse weather conditions. These ATMs were built to shorten and simplify the withdrawal and deposit process. Specifically designed to take in used and soiled notes, typical for rural areas in India, the product development was driven by customer requirements. Equipped with solar power cells to overcome the infrastructure requirements, these ATMs were designed to work in extreme weather conditions (up to $50^{\circ} \mathrm{C}$ ). In rural India where electricity is still a luxury, these solar-based ATMs bypassed the major obstacle in the form of routine availability of electricity. The main goal of Vortex was to build sustainable and socially beneficial solutions that are economic and eco-friendly. This resulted in unique design features and nine design patents, accredited to Vortex, showcasing the pioneering efforts of Vortex in providing best breed of technology at affordable prices to its customers. ${ }^{2}$

The first prototype was deployed at National Rural Employment Guarantee Scheme (NREGS), by Tamil Nadu in 2008 and since then they have collaborated with more than 25 public sector banks for ATM deployments and ATM service management. In 2010, they partnered with State Bank of India, one of the largest banks in the country, and deployed their product - the 'Gramateller Duo' across India. These ATMs came in as revolutionary innovations in the banking industry not just for rural India but also for other similar markets (Jetley, 2014). Their unique features qualified them to be deployed in faraway locations too. By 2011, Vortex started to export its innovative products to eight other developing countries including Nepal, Bangladesh, Djibouti and Madagascar.

Currently, Vortex has set up two manufacturing centres in Chennai and Puducherry producing annually around 12,000 machines and the service centres are distributed across 35 different locations to ensure a 24/7 support. $^{3}$ The anytime, anywhere products of Vortex make it the provider of the lowest 
power-consuming ATMs in the world, the largest brand of solar ATMs worldwide and certified with all major ATM switches.

Furthermore, Vortex is also acknowledged for the high social impact of their innovative solutions. The rural ATMs have enabled 300 million dwellers of rural India to get access to basic banking services like having their own bank accounts.

\section{Vortex Products and Services}

ATMs offered by Vortex, compared to other usual ATMs, consume less power and constitute minimal mechanical and electrical parts, which makes them portable and easily deployable. Their technology is aligned to helping banks to reach rural areas and to include the unbanked population. Furthermore, they provide software solutions for end-to-end ATM services. All of their ATMs are equipped with solar power options for a wider availability in areas where power is rare.

Their products range from the Ecoteller ${ }^{\mathrm{TM}}$ ATM, the world's lowest power-consuming ATM that can even work in harsh conditions, over the Small-Bunch Note Acceptor and Bunch Note Acceptor, cash acceptors that enable depositing of cash and cash transactions anytime and anywhere, to the Ecoteller ${ }^{\mathrm{TM}}$ Mini ATM which can be mounted on wall/table and with a built-in fingerprint authentication option.

In addition to the product offerings, Vortex also offers a complete set of software and services for ATM management, to help banks and ATM service providers to optimize the availability of ATMs and offer specific solution to their customers. They have two different service offerings, one is the 'Vortex hosted model' for the Vortex Data Centre, and the other is the 'Customer hosted model', where the software is installed at the bank's data centre. Both these services are provided to the banks by Vortex. Vortex is also responsible for the ATM management which enables banks to solely focus on their customers (cf. Vortex Engineering Pvt. Ltd, Services, 2013).

Constant cash inflows through sales and by external investors (such as Tata Capital Innovation Fund, Aavishkaar, International Finance Corporation and Oasis Fund), has enabled Vortex to consistently innovate and introduce new services like ATM Management Centers, ATM Managed Services and ATM Advertisement Platforms and increase their market share and product portfolio. The target customer segments of Vortex Engineering are financial institutions such as banks, credit unions and so on, especially in emerging markets. Major banks in India like the State Bank of India, Bank of Maharashtra, Catholic Syrian Bank, Corporation Bank, Federal Bank, IDBI Bank, Indian Bank and IndusInd Bank are existing customers of Vortex ATMs.

\section{Market Conditions and Innovation Drivers}

To understand the motivation behind these Vortex offerings it is helpful to have a closer look on the target market-India. The country has a population of about 1.2 billion residents of which 58.7 per cent are aged between 15 and 54 . The size of the country is about 3 million $\mathrm{km}^{2}$, whereas only 30 per cent of the citizens live in urban areas. About 70 per cent of the population lives in rural areas under simple and sometimes difficult conditions. About 30 per cent of the people live below poverty line. More than 200 different languages are spoken in India. There are approximately 15 official languages and one of them is English, although the latter is now considered an official language in the country at the national level alongside Hindi. The country has an illiteracy rate of about 37 per cent (cia.gov, 2014). 
The economy of India is very diverse. Manufacturing is currently the largest sector, but the fastestgrowing branch is finance, insurance, real estate and business services. Agriculture and mining, which had been the largest sector for many years, contribute 21 per cent to GDP (Bose, 2009, p. 18). These figures correspond with other emerging markets where the demand of personal services increases in line with the rising of available income of the people (Freeman \& Sandwell, 2008, p. 198).

Besides Brazil and Russia, India is one of the fastest-growing economies worldwide (Economist Intelligence Unit, 2017). The projected real GDP growth in 2017 is 7.2 per cent and 7.7 per cent in 2018 (International Monetary Fund, 2017, p. 7). With an average annual rate of 7.6 per cent in next five years, India would be Asia's fastest-growing economy (Economist Intelligence Unit, 2017). In order to achieve economic stability during the economic catch up with the developed countries, one goal of the government is to integrate the rural population into the economic revival process. The first major step for this integration is to provide access to the banking system for all Indian residents. Despite the efforts of the Indian government, only 40 per cent of the rural population has a bank account. In such a situation, ATMs are considered to be a fast and simple solution to increase accessibility to banking services for the rural population (Jetley, 2014).

However, governments and banks constantly face challenges in the deployment of ATMs in rural India. Regular ATM machines are expensive and have high operating costs. They are high-energy consumers and hence become unstable in an environment where there is no constant supply of electricity. Additionally, these machines are not easily portable and therefore it becomes increasingly difficult to transport them to small villages, which lack sufficient logistic infrastructure.

Another challenge that banks are confronted with in ATM deployment is that of security. Because of the high illiteracy rates and lack of exposure to technical knowledge people are sceptical towards modern technologies and are often inefficient in their use. Therefore, banks face this big hurdle of creating confidence in people regarding the usage of ATMs. Governments and banks have the humungous task of providing this information in a way that is easy to comprehend by most of the population considering the different dialects and literacy levels. Another challenge for the banks is to provide access to the customer's account through ATMs. It is unlikely that people from a lower-income background and who have little in common with the modern world will be persuaded to use a four-digit code to get access to their

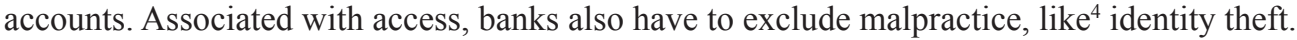

Pollution in rural areas, for example, dusts from unpaved roads, all add to the list of challenges. People are not accustomed to the new and clean currency and might not accept them, doubting their authenticity. Therefore, the ATMs should also accept and issue soiled bank notes (Banerjee, 2010). Beside all these problems with the sensitive ATMs and the special conditions in rural areas, conservative attitudes and bureaucracy in banks hinder the banking business itself to solve these problems (Jetley, 2014). To sum up, there are a lot of challenges the banking sector is facing which means high entry barriers to this nonetheless attractive market. Vortex took on these challenges and used this opportunity to build ATMs with superior features compared to conventional cash machines. Vortex targeted an opportunity of $\sim \$ 500-\$ 600$ million, with its solar-powered ATM, customized for the rural Indian market (Jetley, 2014).

The Vortex ATM solution offers a great opportunity for the banking sector to access inaccessible markets. They have been able to recruit more customers to their banks and offer specialized products (e.g., credits and mini loans) to them. These innovative offerings also led to monetary savings for the end-consumers as an unforeseen benefit (Banerjee, 2010).

Apart from identifying social challenges and using them as a business opportunity, Mr. L. Kannan, founder of Vortex, was keen on social value creation. He established Vortex Engineering to develop 
solutions dedicated for the Indian rural population. Therefore, his personal motivation to develop products for the rural Indian market was also a driving factor behind these ATMs.

\section{Vortex ATM-An Example of Frugal Innovation}

Vortex ATM is a prime example of frugal innovation for BOP. Vortex ATMs are indispensable solutions for the needs of rural India, where power is limited, accessibility and basic services are rare and the language and dialects differ. Motivated by societal drivers, Vortex attempts to solve local problems with local solutions. Vortex realized the problem of financial inclusion of the rural poor in the banking network and focused on developing an affordable and customized solution that could bring banking services to villagers' doorsteps.

It offers a cost-effective, easy to operate and sustainable solution. To overcome resource challenges, it uses the solar power option which needs less than 100 watts for its functioning (Jetley, 2014). Its unique combination of low cost and constraint-based features makes it an appropriate example of frugal innovation. Table 3 shows the nine distinct and unique innovation features of Vortex ATMs that were specifically designed based on core customer requirements and to overcome certain resource barriers.

Table 3. Unique Innovative Design Features of Vortex ATMs

\begin{tabular}{|c|c|c|}
\hline $\begin{array}{l}\text { Innovative Design } \\
\text { Features }\end{array}$ & Description & $\begin{array}{l}\text { Customer Needs/ } \\
\text { Overcome Resource } \\
\text { Constraints }\end{array}$ \\
\hline Gravity-assisted Friction Pick & $\begin{array}{l}\text { Harnessing nature's force to reliably } \\
\text { pick notes with the lowest power } \\
\text { consumption in the world }\end{array}$ & $\begin{array}{l}\text { - Affordable } \\
\text { - Energy efficient }\end{array}$ \\
\hline Dyna Bunch ${ }^{\mathrm{TM}}$ & $\begin{array}{l}\text { Pick-bunch-hop-present for quick } \\
\text { response, lesser power and fewer jams, } \\
\text { resulting in hassle-free operation }\end{array}$ & $\begin{array}{ll}\text { - } & \text { Quick } \\
\text { - Easy-to-use } \\
\text { - Energy efficient }\end{array}$ \\
\hline Double Detach ${ }^{\mathrm{TM}}$ & $\begin{array}{l}\text { When a double-note gets picked, it } \\
\text { not only detects and purges but also } \\
\text { separates them }\end{array}$ & - Reliable \\
\hline Lingua Print $^{\mathrm{TM}}$ & $\begin{array}{l}\text { Enables print receipt in a language of } \\
\text { customer choice }\end{array}$ & $\begin{array}{l}\text { - Localized or customized to } \\
\text { local language }\end{array}$ \\
\hline Beltless Design & $\begin{array}{l}\text { The short transport path eliminates the } \\
\text { need for a belt, while ensuring lesser } \\
\text { power consumption and fewer cash } \\
\text { jams }\end{array}$ & $\begin{array}{l}\text { - Affordable } \\
\text { Q Quick } \\
\text { - Energy efficient }\end{array}$ \\
\hline 60-watt Power Consumption & $\begin{array}{l}\text { Consumes the lowest energy in } \\
\text { minimalistic space, while conserving } \\
\text { energy and drastically reducing up to } \\
\text { almost } 90 \% \text { on electricity bills }\end{array}$ & $\begin{array}{l}\text { - Portable } \\
\text { - Energy efficient }\end{array}$ \\
\hline $\begin{array}{l}\text { Linux OS, Secure and } \\
\text { Guaranteed Lifetime Support }\end{array}$ & $\begin{array}{l}\text { Safer, stable, no frequent patches, } \\
\text { better hardware utilization }\end{array}$ & $\begin{array}{ll}\text { - } & \text { Reliable } \\
\text { - Resourceful }\end{array}$ \\
\hline
\end{tabular}


(Table 1 Continued)

\begin{tabular}{|c|c|c|}
\hline $\begin{array}{l}\text { Innovative Design } \\
\text { Features }\end{array}$ & Description & $\begin{array}{l}\text { Customer Needs/ } \\
\text { Overcome Resource } \\
\text { Constraints }\end{array}$ \\
\hline $\begin{array}{l}\text { One-click Customer Complaint } \\
\text { Resolution }\end{array}$ & $\begin{array}{l}\text { The Vortex-developed ATM } \\
\text { Management Centre pulls up } \\
\text { transaction details and camera image } \\
\text { on demand, simpler and faster anytime }\end{array}$ & $\begin{array}{l}\text { - Simple } \\
\text { [ Quick } \\
\text { - Customizable }\end{array}$ \\
\hline Industry-grade Motherboards & $\begin{array}{l}\text { Configured with extended temperature } \\
\text { range for motherboards and cables } \\
\text { used at the highest levels like NASA for } \\
\text { rugged and failure-free performance }\end{array}$ & $\begin{array}{ll}\text { - } & \text { Reliable } \\
\text { - } & \text { Robust } \\
\text { - } & \text { Rugged }\end{array}$ \\
\hline
\end{tabular}

Source: www.vortexindia.co.in

Being an illustration of frugal innovation, Vortex ATMs also exemplify the social impact of such innovation at a larger level. It showcases how frugal innovations also serve to address societal challenges or service divides that exist in emerging markets. These innovations developed with social vision are not restricted to just the creation of a solution to a problem. They also include innovative strategies which allow for such initiatives to be self-sustainable and accessible to a vast population. By offering banking services in villages Vortex is facilitating the inclusion of the rural population in the growth trajectory of emerging markets.

\section{Notes}

1. Source: www.vortexindia.co.in

2. Ibid.

3. Ibid.

4. The national electronic ID scheme, 'Aaadhar', is now going a long way to overcome this problem. Aadhaar is a unique 12-digit identification number issued by the Indian government to every individual resident of India, and it stands as one of the country's public sector backed innovation projects.

\section{References}

Agarwal, N., \& Brem, A. (2012). Frugal and reverse innovation-Literature overview and case study insights from a German MNC in India and China. In B. Katzy, T. Holzmann, K. Sailer, \& K. D. Thoben (Eds), Proceedings of the 2012 18th International Conference on Engineering, Technology and Innovation (pp. 1-11).

Agarwal, N., \& Brem, A. (2014). A unified innovation approach to emerging markets: Imperatives to play and win the game. 21st International Product Development Management Conference Proceedings: Innovation through Engineering, Business \& Design, European Institute for Advanced Studies in Management, Limerick (pp. 1-26).

Agarwal, N., Grottke, M., Mishra, S., \& Brem, A. (2017). A systematic literature review of constraint-based innovations: State of the art and future perspectives. IEEE Transactions on Engineering Management, 64(1), 3-15.

Banerjee, D. (2010, July 26). Expanding banking in India. The Wallstreet Journal. Retrieved from https://www. wsj.com

Bose, R.K. (2009). India business checklists: An essential guide to doing business. Singapore: John Wiley \& Sons (Asia) Pvt. Ltd.

Brem, A., \& Ivens, B. (2013). Do frugal and reverse innovation foster sustainability? Introduction of a conceptual framework. Journal of Technology Management for Growing Economies, 4(2), 31-50. 
Brem, A., \& Wolfram, P. (2014). Research and development from the bottom up-introduction of terminologies for new product development in emerging markets. Journal of Innovation and Entrepreneurship, 3(1), 1-22.

Christensen, C.M. (1997). The innovator's dilemma: When new technologies cause great firms to fail. Cambridge, MA: Harvard Business Press.

cia.gov. (2014). The world fact book- India. Washington DC: Central Intelligence Agency.

Drazin, R., \& Schoonhoven, C.B. (1996). Community population \& organization effects on innovation: A multilevel perspective. Academy of Management Journal, 39(5), 1065-1083.

Economist Intelligence Unit. (2017). Indian Economy. The Economist Intelligence Unit, London, United Kingdom. Freeman, S., \& Sandwell, M. (2008). Professional service firms entering emerging markets: The role of network relationships. Journal of Services Marketing, 22(3), 198-212.

International Monetary Fund. (2017, April). World economic outlook. International Monetary Fund Publication Services, Washington DC.

Jetley, N. (2014, April 1). Solar ATMs changing the face of banking in India, CNBC. Retrieved from http://www. cnbc.com

Lacy, S. (2011). Brilliant, crazy, cocky. How the top 1\% of entrepreneurs profit from global chaos. Hoboken, NJ and New York, NJ: John Wiley \& Sons, Inc.

Leena S.B. (2011, December 14). Tata capital, Aavishkaar acquiring minority stakes in Vortex. Live Mint. Retrieved from http://www.livemint.com

OECD/European Communities. (2005). Oslo manual: Guidelines for collecting and interpreting innovation data (3rd ed.). Paris: OECD Publications Service.

Prahalad, C.K. (2006). The fortune at the bottom of the pyramid: Eradicating poverty through profits. Upper Saddle River, NJ: Wharton School Publishing.

Prahalad, C.K., \& Mashelkar, R.A. (2010). Innovation's Holy Grail. Harvard Business Review, 88(7/8), 132-141.

Von Krogh, G., \& Raisch, S. (2009). Focus intensely on a few great innovation ideas. Harvard Business Review, October, 87(10), 32.

Vortex Engineering Pvt. Ltd Services. (2013). Overview. Retrieved from https://www.vortexindia.co.in

Zeschky, M., Widenmayer, B., \& Gassmann, O. (2011). Frugal innovation in emerging markets. Research Technology Management, 54(4), 38-45. 


\section{Appendix}

This appendix is given to use this research as a teaching case study. For usage in class, please do not hand out this part. If you have any further questions, feel free to contact the corresponding author.

Case Synopsis

This case is positioned as an illustration of frugal innovation in the Indian banking sector. The case is about solar-powered ATMs developed by Vortex engineering in India to respond to the local requirements of rural population and prevailing social challenges. The case explains the innovation drivers of the Vortex ATMs and discusses the crucial product features that impacted their adoption rate and success within India. These ATMs were well received by the local population based on four main aspects: (a) Affordability, (b) Sustainability, (c) User-friendliness and (d) Customization to the local environment which included additional features like battery operation or portability to overcome infrastructural challenges of rural India.

Target Audience

Master-level students, specifically studying topics like innovation management, international business management or social entrepreneurship, industrial engineering and technology management related fields.

Learning Objectives

- Frugal Innovations have a strong overlap with social innovations.

- Illustration of a bottom-up approach for developing a frugal product.

- Fostering the understanding about frugal innovations and key identifying characteristics.

- Importance of core value and needs identification in new product development for emerging markets.

Teaching Plan and Analysis

- Suggested class time-Two classes of 45 minutes each to focus on frugal and social innovation respectively.

- Suggested student assignment-Asking students to work in teams to brainstorm about the questions given ahead and to give presentation on proposed solutions.

- Brief description for the opening (10-15 minutes).

Frugal innovations are 'good-enough' products, which offer basic functionalities at minimal cost and also facilitate inclusive growth in the developing markets in an economically viable way. The case offers an example of a successful overlap between frugal and social innovations.

- Questions for discussion in the class

- A SWOT analysis on Vortex Engineering: 


\begin{tabular}{|c|c|c|c|}
\hline 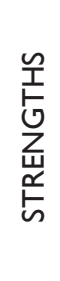 & $\begin{array}{l}\text { - Strong R\&D } \\
\text { - Low price and low cost ATMs } \\
\text { - Extremely energy efficient } \\
\text { - Operational cost advantage } \\
\text { - Durable and operational in harshest } \\
\text { conditions } \\
\text { - Overseas expansion }\end{array}$ & 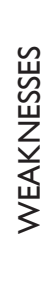 & $\begin{array}{l}\text { - Focused only on emerging markets } \\
\text { - Low brand awareness } \\
\text { - Limited resources }\end{array}$ \\
\hline 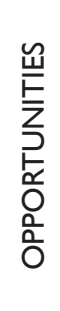 & $\begin{array}{l}\text { - } \text { Low competition in rural markets } \\
\text { - } \text { Export opportunities } \\
\text { - Growing markets at a CAGR }>25 \% \text { p.a. } \\
\text { - Government Initiatives } \\
\text { - Small, agile company } \\
\text { - Smaller overhead } \\
\text { - Scaling - up } \rightarrow \text { volume production } \\
\quad \rightarrow \text { Further down the learning }\end{array}$ & 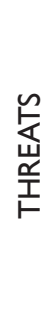 & $\begin{array}{l}\text { - Growing competition } \\
\text { - Advanced technological development / } \\
\text { - Low mants outdated } \\
\text { banks } \\
\text { - Security } \\
\text { - Hacking of the system platform possible }\end{array}$ \\
\hline
\end{tabular}

- Suggestion for further growth of Vortex ATM in developing markets and also in developed market?

- Target countries like India.

- Joint ventures with bigger brands in the developed world.

- As a huge percentage of people not only in Asia but also in Africa use mobile banking and in general mobile services instead of fixed-line services, Vortex could upgrade their ATMs to make them mobile-capable. This way more services might become possible for the rural population.

- What are the main challenges that they can face in developed markets? How can they overcome that?

- Low brand awareness - Joint ventures to overcome.

- Made in India tag-Show past references/Liability of foreignness.

- Concentrate on the environmentally-friendly, low-consumption factor of the ATMs for environment conscious customers in developed markets.

- For increasing social impact and accessibility what other measures can be taken?

- Partnership with government and local agencies.

- Recruiting local influential leaders to increase awareness.

- What does the environment for ATMs in developed, Western countries look like? What are the core requirements for ATMs and the needs of customers? Which adaptions/customizations need to be made in order to serve those markets?

- Brief description for closing (10-15 minutes).

This time should be clearly linked to reinforcing the learning objectives.

- To be successful in emerging markets it is crucial to understand the local environment and core requirements of the consumers. Vortex used a bottom-up approach to understand the local requirement and developed a suitable product for Indian markets. Additionally, it is also an 
example of bringing social benefits to the society with an economically sustainable business model.

General Information on the Case Study Development

The case study was developed as a part of a larger project focused on developing a massive open online course (MOOC) on 'Managing Innovations for Emerging Markets'. The objective of the project was to analyse different types of innovations arising from developing countries and business models adopted that facilitate commercialization of these innovations in an economic and sustainable way. The project was initiated in 2014 and is currently in the phase of data analysis and course module development.

Data collection for the case study was primarily done from secondary sources but we are also thankful to the managing team at Vortex to review our case and validate our findings and implications.

So far in this area of research, scholars have related frugal innovations with sustainability theoretically (Brem \& Ivens, 2013). This case study provides a practical example in the same direction and offers data to validate the relationship. The strong focus on sustainability also offers further scope for exploration in the direction of reverse innovation, like studying the acceptance of such high-tech innovation developed in emerging markets in the developed world. 